\title{
Testing Russian Stock Market Efficiency Using Event Studies: Impact of Credit Ratings Changes
}

\section{Svetlana Avrutskaya $\bowtie$}

$\mathrm{PhD}$, Associate professor, Department of Management and Marketing

E-mail: avrutskaya-sg@ranepa.ru

$\underline{\text { ORCID }}$

Mendeleev University of Chemical Technology of Russia,

Moscow, Russia

Associate professor, Department of Quantitative Methods in Management, Institute of Business Studies

The Russian Presidential Academy of National Economy and Public Administration

Moscow, Russia

\section{Elizaveta Maricheva}

$2^{\text {nd }}$ year master's student

E-mail: mari4eva.liza@gmail.com

ORCID

The Russian Presidential Academy of National Economy and Public Administration

Moscow, Russia

Journal of Corporate Finance Research, Vol. 15, No. 2, pp. $42-54$ (2021)

For citation: Avrutskaya, S. and Maricheva, E. (2021) “Testing Russian Stock Market Efficiency Using Event Studies: Impact of Credit Ratings Changes", Journal of Corporate Finance Research | ISSN: 2073-0438, 15(2), pp. 42-54. doi: 10.17323/j.jcfr.2073-0438.15.2.2021.42-54.

Received 10 April 2021 | Peer-reviewed 18 April 2021 | Accepted 19 April 2021 


\section{Abstract}

Event study is a widespread technique for testing the semi-strong form of the market efficiency hypothesis. Among traditionally studied events, changes in corporate credit ratings by rating agencies have a special importance, since rating agencies use both publicly available and insider information. Studies of developed and emerging markets point to different reactions of stock prices to rating upgrades and downgrades and identify several factors affecting the scale of this effect, including the size and liquidity of the stock market, the level of regulation of the industry, the market capitalization of the company, the status of the rating agency, and others.

On the Russian market, the impact of credit rating upgrades and downgrades on stock prices has not been investigated so far. Ongoing studies of other events affecting stock prices show that the market's reactions are pretty much in line with those of developed markets, despite its immaturity, limited transparency, high volatility, narrowness and low liquidity, as well as the small number of significant events.

In this article, we evaluate the level of efficiency of the Russian stock market and analyse the reaction of stock prices to changes in issuer credit ratings by international rating agencies using the traditional event study methodology in a narrow event window of 31 days over the period 2016-2020 on a sample of 49 public companies. We show that credit rating upgrades do not lead to statistically significant positive abnormal returns. Visual analysis demonstrates that rating downgrades result in substantial negative abnormal returns. This effect varies for financial and non-financial companies and companies with low and high capitalization yet differs from the effects observed for developed markets; nevertheless, these abnormal returns are not statistically significant. Still, there are grounds to conclude that the Russian stock market is not efficient in the semi-strong form and is closer in its characteristics to emerging markets, which is important information for investors, as it permits them to develop profitable trading strategies.

Key words: market efficiency, semi-strong form, stock prices, event study, transparency, credit rating, abnormal return, cumulative abnormal return 


\section{Introduction}

Studies of the efficiency of the Russian stock market began as early as the 1990s. While tests of the weak form of market efficiency, according to which stock prices are indicative of all previous information about a company, are somewhat contradictory [1-4], researchers mostly believe that the Russian stock market is efficient in the weak form.

However, the issue of Russian market efficiency in the semi-strong form, which implies that all publicly available information about the issuer is immediately and comprehensively included in the market value of its securities, remains open. In a semi-strongly efficient market, security quotations should not respond to new information (the announcement of a so-called event), because all relevant information is taken into consideration in the current price. So, by considering the response of a given market to new information, one may estimate its efficiency, which, in turn, serves as a key factor for investors when they take decisions about the purchase and sale of securities.

The range of events whose influence on stock prices is traditionally investigated is broad: from macroeconomic to corporate events, including political and legislative changes, announcements of earnings and dividends, issue and split of shares, mergers and acquisitions, change of accounting policies, etc. One such event is a change in the issuer's credit rating.

Credit ratings are assigned by rating agencies (RAs), expressing the independent opinion of analysts about the relative level of credit risk, i.e., the issuer's (sovereign, institutional or corporate borrower's) ability to fulfil its obligations completely and in due time. Ratings also allow the evaluation of the credit quality of certain debt securities and their default probability.

Credit ratings are determined on the basis of historical and current information as well as anticipated future events and are therefore predictive in nature. It is natural that RAs specializing in credit risk assessment play a crucial part in the evaluation of the creditworthiness of issuers and the investment quality of their debt instruments. While there are dozens of RAs across the globe (including such Russian agencies as National Rating Agency, Expert RA, AK\&M, and RusRating), there are only three international leaders: Standard \& Poor's, Fitch Ratings and Moody's Corporation, which control over $90 \%$ of the global debt market.

RAs constantly rate issuers and debt securities using both publicly available and insider information obtained directly from the issuer in order to detect the factors which may influence its creditworthiness. When such factors are identified, RAs may adjust the rating or revise its upward or downward forecast, changing their opinion about the relative level of credit risk. As long as the credit rating provides significant information for investors, a change in it should entail a change in the market value of the issuer's securities. This concerns both debt and equity securities.
Thus, a series of questions arises:

- Is a discontinuous change of credit rating a factor that can in itself influence the market value of the issuer's fundamental financial instruments? Or do RAs that adjust ratings just register continual changes in the market value from information entering the market about the issuer's status, with some elements of forecasting?

- Does the response to a change of the credit rating of the quotation of debt and equity securities differ?

- Are there differences in the response of security quotations to information about the upgrade and downgrade of credit ratings?

- Does the response of security quotations depend on industry, company size and other factors?

- Does the response of security quotations depend on the maturity of the stock market?

- Does the RA's status (national / international) influence market response to rating change?

\section{Literature Review}

Early studies of the influence of credit rating changes on stock prices started with the US market (a useful list of literature is found in [5], for example). Employing monthly returns and different time horizons, they gave contradictory results. Current studies (from earlier [6] to more recent [7] papers), which make use of daily returns and consider the influence of credit rating change in a narrow event window, yield more consistent results (this may be due to the fact that the amount of information that is publicly available and relevant for share price formation is increasing in volume and spreading at an ever-growing rate). These studies share the conclusion that, unlike upgrades, downgrades significantly influence the market value of shares. This may be due to the fact that companies more willingly disclose positive information that upgrades credit ratings. This information influences financial quotes in advance, while negative information is withheld, and rating downgrades come unexpected.

The regularities identified for the US market also exist for other large markets such as Germany [8; 9], other European countries [10], and Australia [11;12]. Thus, even developed markets are not efficient in the semi-strong form.

The regularities found for large markets may be distorted if national RAs change ratings. For example, [13] considers the influence of credit rating changes by the Japanese national RA R\&I on the stock prices of companies listed on the Tokyo Stock Exchange, which surpasses the London Stock Exchange in capitalization. It shows that the market responds positively to negative information and vice-versa. As to local markets, even less efficiency may be expected from them due to limited liquidity, information, and analysts' attention. Nevertheless, the effect on markets in Norway [14] and Nordic countries in general [15] corresponds to the regularities of large markets. At the same time, it was found that the New Zealand market responds to positive 
as well as negative information about the revision of ratings and forecasts [16]; a rating and forecast upgrade was accompanied by a significant abnormal positive return in Italy [17]; and a rating downgrade and a negative forecast were accompanied by an abnormal positive return in Portugal [9]. However, it is difficult to make informative conclusions from a small sample, especially for such a volatile market as Portugal.

A limitation for many studies is the fact that a sample consists, as a rule, of blue chips of large transparent public companies - for example, companies included in the S\&P 500 index. At the same time, researchers point out that the influence of events is more significant for small-capitalization companies [12; 14].

In addition, a stronger market response is observed when a rating changes from the investment to the speculative level $[7 ; 12]$.

Researchers mainly associate sector influence with the existence of regulation. We may assume that the market response is much weaker if a company belongs to a regulated industry (banks, insurance companies), because such companies have to disclose more information, and the regulation procedure in itself is a source of information for the market.

The first studies of the influence of credit rating changes on the stock prices of banking groups [18] failed to reveal any differences in the response of banks in comparison to manufacturing companies. Later studies $[10 ; 17]$ pointed to a less significant effect of downgrades on financial companies, which may be explained by more serious requirements for information disclosure.

Recent studies of the influence of bank credit rating changes on bank stock prices on US [19] and European [20;21] markets identified abnormal returns from rating downgrades and upgrades, which may be due to the research period (a wide-scale rating downgrade after the crisis of 2008) and the sample structure (a large share - over 50\% of events in countries with presumably less efficient markets such as Italy, Spain, and Greece).

A study of the influence of rating agency status (Big Three / others) and the economic development of the country on bank credit ratings [22] showed that bank shares are sensitive to information about rating downgrades, that the influence of rating upgrades manifests itself in countries with average rating actions by economic development, and that the market responds more to international than national RAs.

An analysis of events on emerging markets, in particular in BRICS countries, is of special interest. [23] studies the response of the stock market to issuer rating changes in 26 countries included in the MSCI Emerging Market Index and shows abnormal returns in response to rating upgrades as well as downgrades. It argues that stock prices respond more to changes in ratings by international agencies than by national ones. Studies of the Indian stock market confirm this [24-26]. Statistically significant abnormal returns in the case of rating changes (upgrades and downgrades) by international RAs [27] were found for the Bra- zilian market. Indeed, the greatest informative effect was produced by rating downgrades. In fact, Pinto [28] found a statistically significant abnormal return only in the case of a rating downgrade. A study of the influence of credit ratings on the stock prices of companies on the Johannesburg Stock Exchange (RSA) in 2005-2015 [29] showed that, just as in developed economies, this market shows a significantly negative response only to rating downgrades. The markets of Brazil and RSA, whose ratings are assigned by international RAs, approximate advanced markets in their efficiency.

One may assume that the effect of company size will be more significant for emerging markets due to the limited available information. In particular, one found both an immediate and a long-term significant influence of rating change on the stock prices of small and mid-sized companies on the Bombay Stock Exchange in 2010-2014; moreover, the influence of rating downgrades was shown to be more apparent than the influence of upgrades [30].

A study of sector influence in India showed a statistically insignificant negative abnormal return in the case of a bank rating upgrade and a statistically insignificant positive abnormal return in the case of a downgrade [31]. However, the small sample made it difficult to generalize. At the same time, similar results were obtained in Pakistan [32]: a significant positive response of the market to bank rating downgrades by the Pakistan Credit Rating Agency and an insignificant negative response to rating upgrades.

On the Chinese market, the study of events such as the influence of credit rating change on stock prices has started only recently and has been conducted on a one-time basis. As late as 2018, there were only national RAs on the market, whose ratings are criticized for their methodology and reliability. The most relevant publication for the present study is [33], which compares the influence of credit rating changes on stock prices on the stock exchanges of Mainland China and Hong Kong and shows that both markets are inefficient, although the Hong Kong market is more efficient and has more characteristic features resembling developed markets. It also studies the influence of the reasons for bond rating downgrades on stock prices [34].

[35] made an attempt to sum up different empiric research by using meta-analysis to confirm the results of 62 studies performed over 30 years that rating downgrades are accompanied by significant abnormal returns, especially in the USA, while rating upgrades exert no significant impact, irrespective of the market. The following factors may be considered significant for research: market maturity (lower sensibility of emerging markets to rating downgrades); affiliation with the non-financial sector; a more apparent market response to rating changes after 2000; and preliminary announcements of inclusion on the CreditWatch list (ratings under review): a relatively higher response in the case of positive forecasts and a relatively lower response in the case of negative ones. In addition, the sample size and the employed statistical tools and procedures of preliminary data cleaning exert an influence. 
On the Russian market, the first statistical investigations of the influence of events on the price of market shares were conducted as far back as 1990s and took into consideration the specifics of Russian events at that time. In particular [1], studied the influence of announcements of auctions in which state-owned stakes were sold as a part of cash privatization in 1995-1996. Today, authors consider methodological issues [36] as well as the effects of certain political [37] and corporate events, including the influence of dividend pay-outs on the market value of Russian companies [38; 39]; the announcements of mergers and acquisitions [40-42]; and the cross-listing of Russian companies [43]. Thus, the range of considered events is quite broad.

The article by A. Pogozheva [44] comes closest to the present study. It evaluates the informational significance of analytical reports by investment banks about Russian companies and shows that improvements in the recommendations of investment bank analysts led to a significant growth of stock prices of Russian issuers two or three days after the event, while deteriorating recommendations led to falling stock prices. Moreover, these results are stable for different data samples and are observed both at the MICEX and the London Stock Exchange. The study by Khlyupina and Berzon [45] shows that the growth of stock prices stemming from positive recommendations by analysts exceeds their fall from negative recommendations. In addition, the influence of a negative event is more time-spaced than the influence of a positive event. The authors conclude that a revision of recommendations does not have an immediate impact on prices, and, hence, the Russian stock market is inefficient.

The objective of the present paper is to study the influence of information about changes in the credit ratings of Russian issuers on their stock prices in order to evaluate the efficiency of the Russian stock market. As far as the authors know, no similar studies have been conducted on the Russian market so far.

\section{Research Methodology}

The modern methodology of event study (Russian literature also uses the term "event research") is based on papers by Ball and Brown [46] and Fama and Fisher [47]. It has been described in detail numerous times (see, for example, [48] and the Russian-language works [49-51]). It is based on a comparison of the actual return on assets during the period immediately before and after the event ("event window") with historic or expected returns in the case of the absence of an event in order to identify abnormal returns. Modifications of the methodology proposed by different authors relate mainly to the assessment of expected returns and the statistical processing of data for making conclusions. When the research methodology is applied to diverse events within different time intervals, there is no prevailing method that may be applied to all possible events.

Bowman proposed a five-stage structure of event study [52]:
1. Choice of an event or type of event for analysis

This may be a single event (for example, political or legislative changes which have an impact on all assets in the economy) or a certain type of events taking place in various companies at different times (announcement of earnings or dividends, issue or split of shares, etc.). In the latter case, event synchronization is necessary. It is achieved by adjusting the event to zero time and choosing an event window of a single duration.

2. Forecast of the expected response of security prices to the event

Research hypotheses tend to be generated at this stage: what will be the expected response of the prices of different assets to the event?

3. Choice of the method of abnormal (excess) returns evaluation as the difference between the actual and expected (normal) returns

In order to evaluate normal returns, statistical models (Comparison Period Mean Adjusted Model), market models on the basis of CAPM with various ways of calculating $\beta$, and economic multifactor models (Fama and French) may be used.

4. Adjustment and grouping of calculated abnormal returns

While abnormal returns may be studied separately, assets are usually grouped into uniform portfolios to verify the hypotheses proposed at stage 2 . Cumulative average abnormal returns (CAAR) [47] or the abnormal returns index (MI) [48] are calculated for the portfolios.

5. Analysis of the results with the help of descriptive or formal statistics methods

The results of calculations may be presented in tables or diagrams or processed by applying parametric statistical methods.

Furthermore, it has been shown [53] that this structure may be basically reduced to three stages:

1) Defining the studied event and its time frame.

2) Choice of the "standard" model to assess normal returns.

3) Calculation and analysis of abnormal returns in the event window.

This is the structure used in the present paper.

We analyse the impact of a change of credit rating by the Big Three international RAs - S\&P Global Ratings, Moody's Investors Service and Fitch Ratings - on the stock prices of 49 public joint-stock companies from various industries that have different market capitalizations and shares traded on the Moscow Stock Exchange. 109 cases of rating upgrade and 26 cases of rating downgrade were considered.

The chronological framework of the research was limited by the period 2016-2020, because the sovereign credit rating of the Russian Federation was lowered in early 2015, entailing a downgrade in the ratings of many Russian raw material, telecommunication, and infrastructure companies. For many companies, the rating forecast became neg- 
ative. Therefore, in order to avoid the influence of previous events on the general statistics, we only analysed data after 2015. Information on changes in long-term ratings in national currency was obtained from the sites of the rating agencies S\&P Global Ratings, Moody's Investors Service and Fitch Ratings. The stock prices (closing prices) within an evaluation window of 100 trading days immediately before the event window and an event window of 31 days $([-15 ;+15]$, with only trading days being taken into consideration) were taken from the website of the Moscow Stock Exchange. The limited length of the evaluation window of 100 trading days (approximately five calendar months) was due to the fact that, for many companies, a change of credit rating is quite a frequent event that took place several times (up to 5-7) during the research period.

The sample was analysed for errors. We excluded changes of ratings which overlapped with other events within the evaluation or event window that could result in a change of stock prices (for example, the suspension of trade, additional issues, split of shares, etc.) as well as sequential rating changes (within the event window) by two or more RAs. In the latter case, we took into consideration only the earliest event.

The (actual) daily returns were calculated using the following formula:

$R_{i, t}=\frac{P_{i, t}}{P_{i,(t-1)}}-1$,

where $\mathrm{R}_{\mathrm{i}, \mathrm{t}}$ is the actual return on share $i$ at time $\mathrm{t}$,

$P_{t}$ is the price of share $\mathrm{i}$ at time $\mathrm{t}$,

and $P_{t-1}$ is the price of share $\mathrm{i}$ at time $\mathrm{t}-1$.

The normal return was defined by the constant average return method:

$$
N R_{i}=\frac{1}{T} \sum_{t=t_{1}+1}^{t_{2}} R_{i, t}
$$

where $t_{1}, t_{2}$ are the lower and upper evaluation window edges, respectively,

and $\mathrm{T}$ is the number of calculated returns $\left(\mathrm{T}=\mathrm{t}_{2}-\mathrm{t}_{1}=99\right)$.

The abnormal returns (excess returns) were calculated using the following formula:

$$
A R_{i, t}=R_{i, t}-N R_{i} \text {. }
$$

The average abnormal returns in a sample of $\mathrm{N}$ companies were defined using the formula

$$
A A R_{t}=\frac{1}{N} \sum_{i=1}^{N} A R_{i, t} .
$$

The cumulative average abnormal returns within the event window $\left(t_{1} ; t_{2}\right)$ were calculated as follows:

$$
C A A R\left(t_{1} ; t_{2}\right)=\sum_{t=t_{1}}^{t_{2}} A A R_{t} \text {. }
$$

In accordance with the methodology accepted for other markets, samples were compiled to verify the following hypotheses:
Hypothesis 1: stock prices respond more to rating downgrades than to rating upgrades (109 cases of rating upgrades and 26 of downgrades).

Hypothesis 2: the response to rating downgrades is more significant for non-financial companies (4 rating downgrades of financial companies and 22 of non-financial companies).

Hypothesis 3: the response to rating downgrades is more significant for low-capitalization companies (6 events for high-capitalization companies and 20 events for low-capitalization companies).

The obtained results were visually assessed using diagrams of cumulative abnormal returns, and their statistical significance was verified with the Student's Test (significance level of 0.05).

The confirmation of these hypotheses would mean that the Russian market is inefficient in the semi-strong form and that stock prices respond to credit rating changes in the same way as on developed markets.

\section{Special Features of the Sample}

The Big Three of international RAs (S\&P Global Ratings, Moody's Investors Service and Fitch Ratings) operate on the Russian market. Currently, international RAs assign credit ratings to over 200 issuers. The sample comprises changes by international RAs of the credit ratings of Russian issuers whose ordinary shares are traded on the Moscow Stock Exchange. The sample structure is fairly unusual. In particular, there is only a limited number of companies whose shares are traded on the market (at present, a little over 200 companies, 49 of which are included in the sample).

The sample mainly consists of raw material, metallurgic, power, transportation and telecommunication companies. They are the largest public companies and, due to their export orientation and/or high status on the Russian market, they are interested in the evaluation of their creditworthiness by international rating agencies. Many of these companies cooperate with several RAs, including the Russian agencies ACRA, Expert RA, National Rating Agency (NRA) and National Credit Ratings (NCR). There are no smaller companies in the sample because of their local orientation. As a result, international RA ratings are not characteristic for them, and they mainly cooperate with Russian RAs.

Some large organisations such as X5 Retail Group, Yandex, and OZON, despite their Russian origins, are officially foreign issuers and are therefore not included in the sample.

The period of 2016-2020 was characterized by the recovery of the Russian economy, including the Russian stock market, after the devaluation of the rouble in October 2014, the imposition of economic sanctions by Western governments, and the downgraded sovereign credit rating of Russia and the downgraded ratings of the largest Russian issuers. This may explain why credit rating upgrades prevail over downgrades as events. 
Nevertheless, it should be noted that the majority of ratings of Russian issuers are at the speculative level: only 6 out of 49 issuers in the sample had credit ratings of investment level at the beginning of the considered period (of which 4 were assigned by one RA, with ratings by other RAs being speculative) and 24 at the end of 2020 . Often the shift from the speculative to the investment category took place step by step. Although issuers had acquired speculative status as a result of all the rating downgrades, only PJSC Megafon and PJSC Polus had investment ratings initially. Given such a small sample size, there is no point in trying to define the influence of the initial rating (investment / speculative).

The intensity of rating actions within the considered period differed from company to company: there were numerous rating actions related to a certain issuer, including rating changes by several RAs simultaneously or only by some RAs while other RAs left the ratings unchanged. For many of the largest issuers such as PJSC Rostelecom or PJSC Uralkali, the rating actions within the considered period were limited to the adjustment or confirmation of forecasts, while the overall ratings remained unchanged; such companies were not included in the sample. RAs often took rating actions with respect to several (several dozen) issuers simultaneously (S\&P on 28 January 2021, Moody's on 28 January 2018 and 12 February 2019, Fitch on 20 August 2019). At the same time, the rating actions of several RAs with respect to a specific issuer coincided very rarely in time.

Although RAs (including international agencies) cooperate a lot with Russian banks, insurance companies and investment corporations by assigning credit ratings both to issuers and to their debt instruments, the sample includes a very small number of financial organisations, because the majority of Russian banks and other financial companies are not public entities, and their shares are not traded on the stock market.

On the Russian market, the criterion for big business is the amount of revenue (over RUB 2 billion) and the number of employees (more than 250 employees) ${ }^{1}$. According to these criteria, all the companies in the sample may be considered to be big businesses. However, the main criterion in Western countries is the market capitalization of a company: market capitalization exceeding $\$ 10$ billion is generally considered to be high. According to the latest data ${ }^{2}$, there are 14 such companies on the Russian market. Within the studied period, only one company from the sample - PJSC Magnit - met this criterion on the date of rating change. Therefore, for the purposes of our study, issuers with capitalization exceeding RUB 200 billion are classified as high-capitalization companies. The market capitalization of companies was calculated on the date of rating change.

\section{Research Results}

The visual assessment of the results shows that an announcement of credit rating upgrade (Figure 1) leads to a fall in stock prices. This contradicts expectations and observed effects in developed markets; however, it is consistent with data from other emerging markets. Besides, in the event window, prices fall first, and then increase, with a period of stabilization immediately before the announcement of the rating upgrade. They subsequently fall on the $4^{\text {th }}$ and $5^{\text {th }}$ days before returning to their initial levels by the end of the event window.

However, the high volatility of average abnormal returns in comparison to their absolute value (AAR root-meansquare deviation of approximately $1.4-1.8 \%$ ) prevents us from making significant conclusions. This is confirmed by t-statistics for AAR (Table 1) that show a statistically significant fall in stock prices immediately after the event as well as on the $-11^{\text {th }}$ and $4^{\text {th }}$ days and a rise in prices on the $-5^{\text {th }}$ day. The rise and fall of stock prices on the indicated dates are shown in the figure; however, they are so insignificant that it would be hard to develop income-generating trade strategies on their basis. T-statistics of cumulative average abnormal returns (CAAR) reveal no statistically significant values.

The visual analysis of the response of stock prices to a rating downgrade shows that a fall in prices takes place before the event, a significant reduction in prices occurs on the next day after the rating downgrade, and prices further decrease for five days before starting to grow gradually, almost attaining their initial values. However, t-statistics (Table 1) indicate only one statistically significant decrease in average abnormal returns that occurs 11 trading days before the event. Other values of average and cumulative abnormal returns are not statistically significant. One may assume that this is due to a prolonged and gradual reduction of prices as well as their high volatility and the smaller size of the sample. Thus, hypothesis 1 is confirmed at the empirical level yet not statistically.

A comparison of the response to a rating downgrade of financial and non-financial companies (Figure 2) indicates that the prices of shares of non-financial companies show a significant decrease when a rating downgrade occurs and continue to fall up to the $8^{\text {th }}$ day before returning almost to their initial level. However, only the negative average abnormal return on the $-11^{\text {th }}$ day is statistically significant, while CAAR values are statistically insignificant.

\footnotetext{
${ }^{1}$ Regulation of the Government of the Russian Federation of 04.04.2016 No. 265 "On the Limit of Revenue Earned by Business Operations for Each Category of Small and Medium Business Entities".

${ }^{2}$ The most expensive Russian public companies - 2021. RIA Rating, 04.02.2021. URL: https://riarating.ru/corporate_sector/20210204/630194247.html (accessed on 15.02.2021).
} 
Figure 1. Cumulative average abnormal returns (CAAR) in the case of credit rating upgrade and downgrade

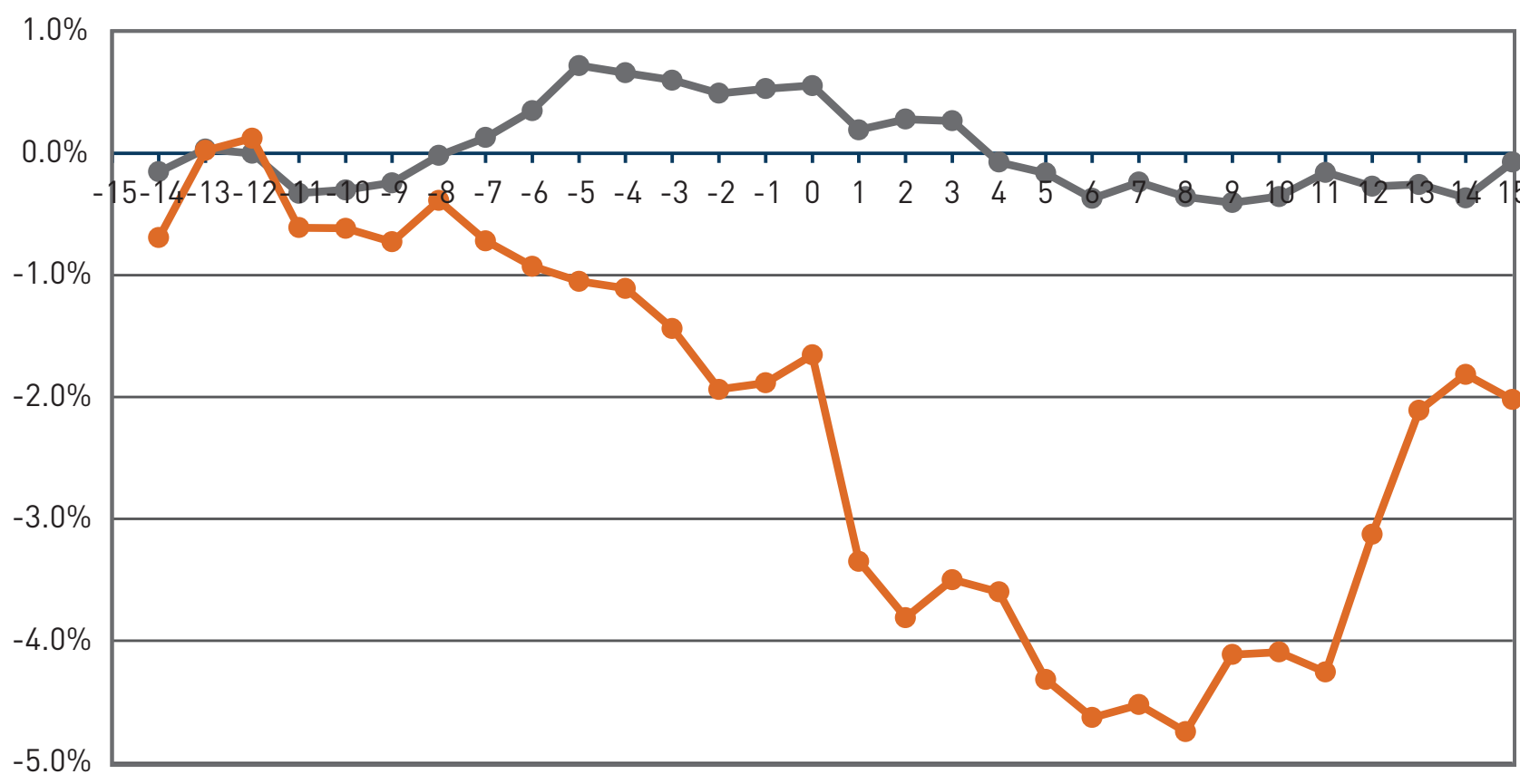

- rating upgrade - rating downgrade

Figure 2. Cumulative average abnormal returns of financial and non-financial companies due to credit rating downgrades

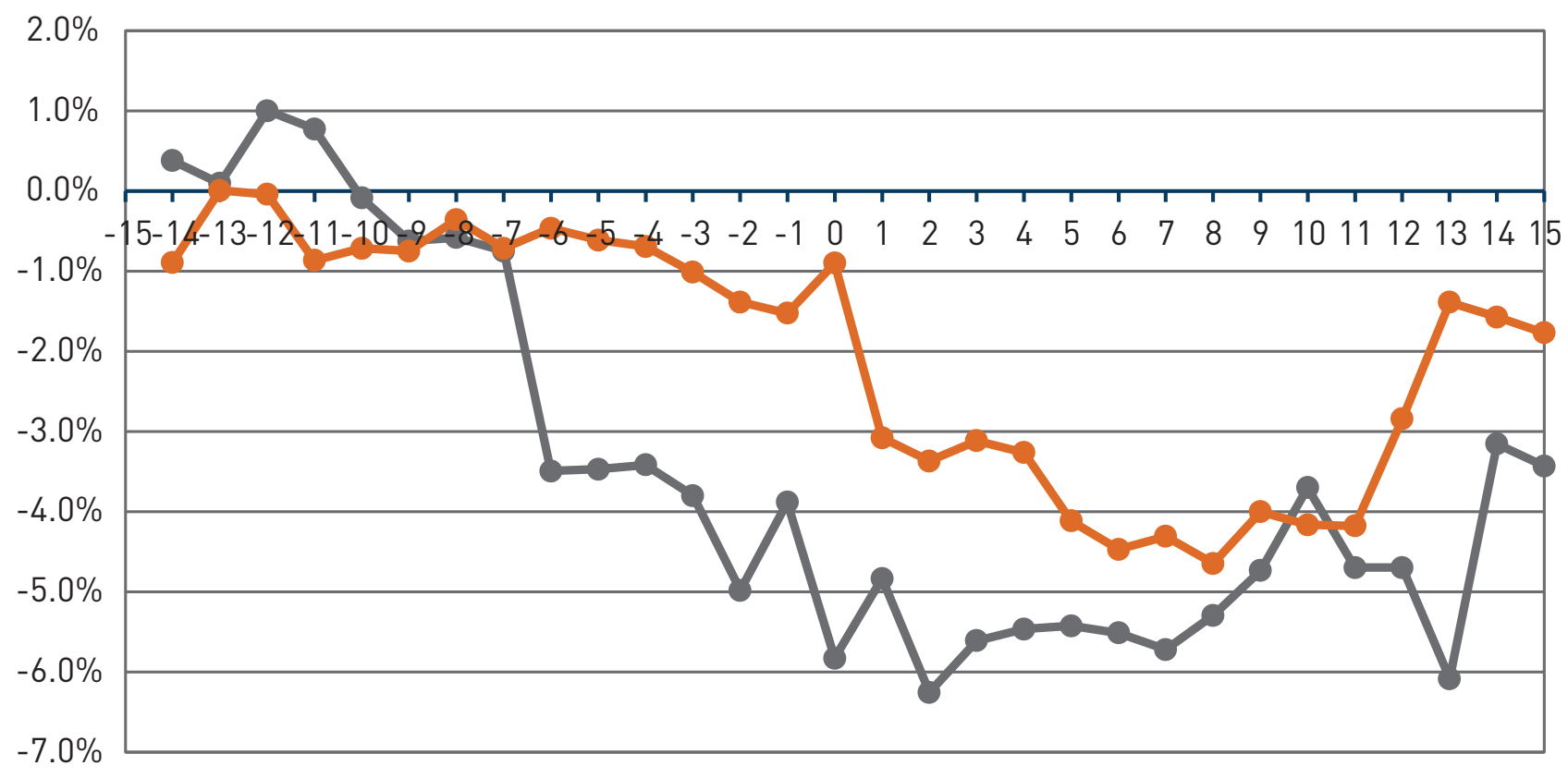

- financial companies non-financial companies 
Table 1. Testing the significance of average abnormal returns (AAR) and cumulative average abnormal returns (CAAR)

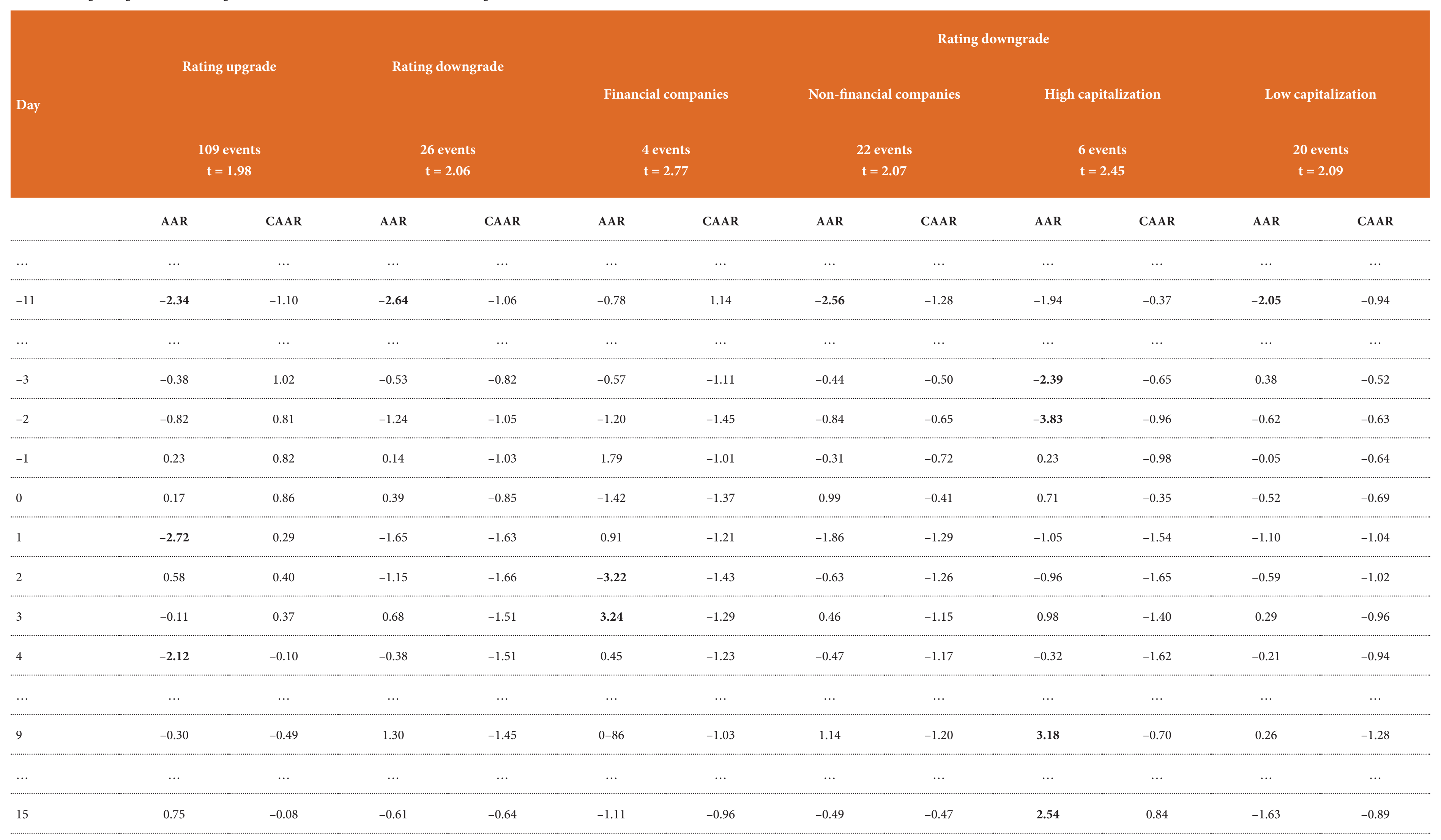


Figure 3. Cumulative abnormal returns for high- and low-capitalization companies when credit rating downgrades

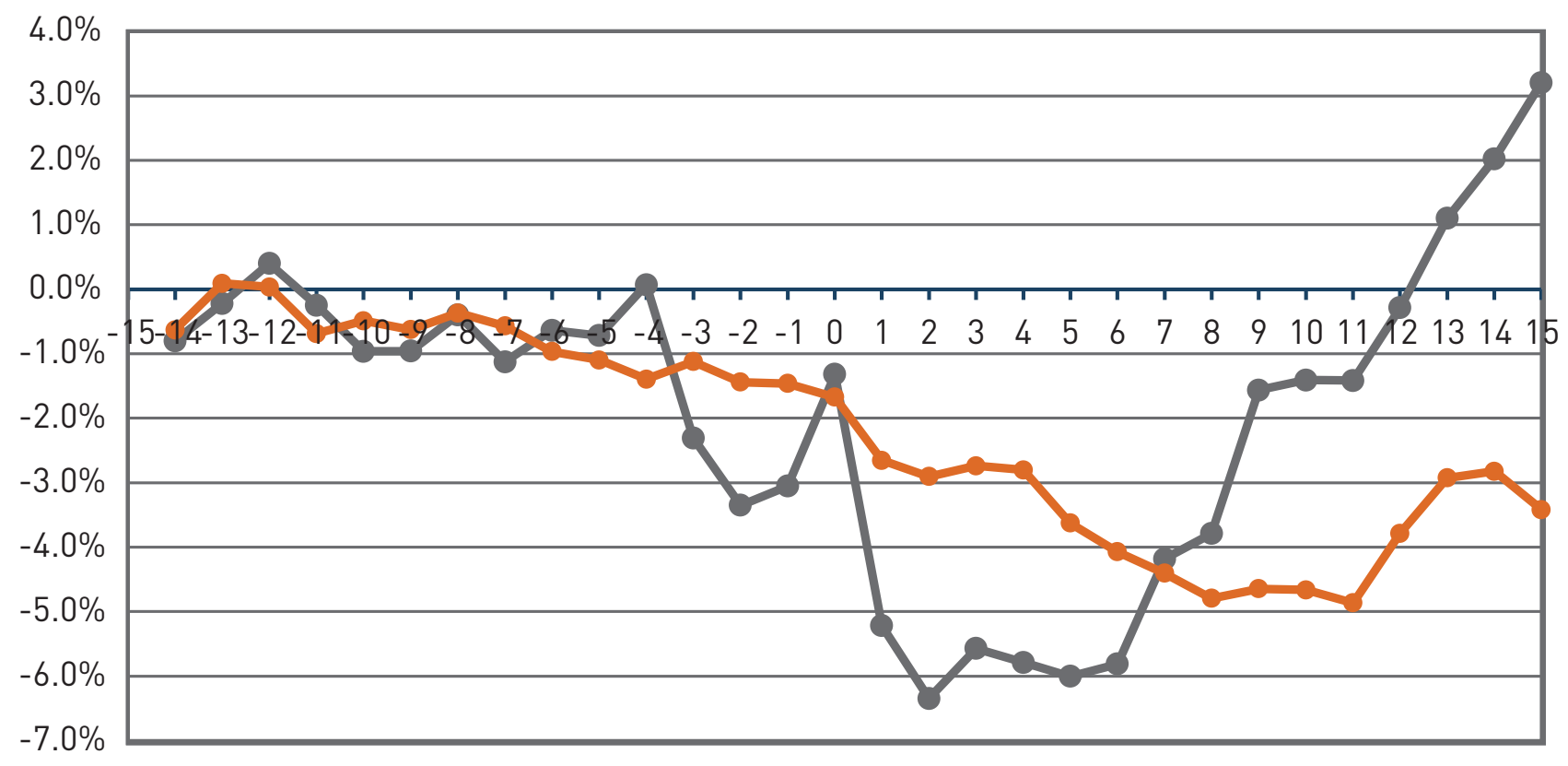

high capitalization $\longrightarrow$ low capitalization

For financial companies, the price reduction begins long before the announcement of the rating downgrade, which may be due to more serious requirements for information disclosure, including negative information that enters the market in the period preceding a rating action. Prices do not return to the old level within the event window. T-statistics (Table 1) show that there is a statistically significant negative AAR value on the $2^{\text {nd }}$ day and a positive value on the $3^{\text {rd }}$ day. However, the assertion of the high significance of the obtained results for financial companies is hardly reasonable due to the small sample (four events). Thus, empirical analysis suggests that shares of financial and non-financial companies behave in a different way within the event window. However, the response of financial companies is more profound and starts earlier, and so hypothesis 2 is also rejected.

The difference in the behaviour of stock prices of companies with high and low capitalization is noteworthy (Figure 3). The stock prices of companies with low capitalization decrease gradually long before the event, a significant fall is observed immediately on the date of the credit rating downgrade, and the prices decrease further on the $5^{\text {th }}$ day. Stock prices do not return to their initial level within the event window. Statistically significant values of AAR and CAAR have not been identified despite the relatively large sample size (20 events).

The stock prices of companies with high capitalization seem to be stable during the period preceding the rating downgrade. A statistically significant negative average abnormal return occurs only on the $-11^{\text {th }}$ day. Despite its strongly pronounced nature, the decrease in AAR on the date of the event is not statistically significant, nor is the subsequent rise of stock prices to a level exceeding the initial one. This may be due to a high volatility of share prices and the small sample. In general, the response of shares of high-capitalization companies to rating downgrades is more significant. This may be due to their higher liquidity, on the one hand, and the greater optimism of investors about large companies, on the other. Thus, hypothesis 3 is confirmed neither at the empirical nor at the statistical level.

The statistically significant negative values of abnormal returns 11 trading days (14-15 calendar days) before the announcement of the rating change, whether an upgrade or a downgrade, are noteworthy. We may conjecture that information about the start of the procedure of rating change by RAs becomes available to the market at this time despite its confidentiality and has an impact on stock prices.

\section{Conclusions}

The analysis of the response of stock prices to announcements of credit rating upgrades (statistically significant decreases of returns) suggests that the Russian stock market is inefficient in the semi-strong form. At the same time, the absence of a statistically significant response to the announcement of credit rating downgrades does not provide sufficient grounds to consider the market to be efficient; it is most likely the result of the limited size and specific characteristics of the sample (a small number of rating downgrade events and a small number of financial companies and high-capitalization companies). Taking into consideration the market's immaturity, high volatility, narrowness and low liquidity and the small number of significant events, one can make the general conclusion that the Russian stock market is not efficient in the semi-strong form. When rating agencies monitor issuers and adjust their credit ratings and forecasts, they provide significant informa- 
tion to the market. This is less true of positive events when RAs play a certifying role of sorts, using the credit rating upgrade to register positive information that has become available to the market and on the basis of which the rating action is performed. At the same time, the response of stock prices to credit rating downgrades is indicative of the fact that the market obtains new and unique information.

Our analysis of the influence of industry and company size uncovered regularities different from the ones observed in developed markets: the response of the stock prices of financial companies to credit rating downgrades was more pronounced, as was the response of the stock prices of high-capitalization companies. However, it is difficult to assert the stability and statistical significance of these regularities due to the high volatility of stock prices and the small size of the sample, as well as other factors apart from the rating downgrade which influenced stock prices within the event window.

In general, the comparison of our results to the data obtained from other markets shows that, in its response to credit ratings change, the Russian market has more in common with emerging markets than with developed ones.

The understanding of the impact of credit ratings on stock prices is important for various market players and, in particular, for asset and asset portfolio managers who take investment decisions. The rather insignificant response of stock prices to credit rating upgrades suggests that income-generating trade strategies are unlikely to be developed on their basis. However, it is possible to develop efficient trade strategies with returns exceeding transaction costs on the basis of RA announcements of credit rating downgrades.

\section{References}

1. Buklemishev O.V., Malyutina M.S. Analysis of information efficiency of the Russian stock market. Ekonomika i matematicheskie metody = Economics and Mathematical Methods. 1998;34(3):77-90. (In Russ.).

2. McGowan C.B. An analysis of the technical efficiency of the Russian stock market. International Business \& Economics Research Journal, 2011;10(10):31-44. https://doi.org/10.19030/iber.v10i10.5977

3. Abrosimova N., Dissanaike G., Linowski D. Testing weak-form efficiency of the Russian stock market. SSRN Electronic Journal. 2002. https://doi. org/10.2139/ssrn.302287

4. Darushin I.A., L'vova N.A. Assessing the Russian financial market efficiency by a non-parametric method. Finansy $i$ kredit = Finance and Credit . 2014;(48):14-24. (In Russ.).

5. Norden L., Weber M. Informational efficiency of credit default swap and stock markets: The impact of credit rating announcements. Journal of Banking \& Finance. 2004;28(11):2813-2843. https://doi. org/10.1016/j.jbankfin.2004.06.011.
6. Dichev I.D., Piotroski J.D. The long-run stock returns following bond ratings changes. The Journal of Finance. 2001;56(1):173-203. https://doi. org/10.1111/0022-1082.00322

7. Reddy K., Bosman R., Mirza N. Impact of credit ratings on stock returns. Buletin Ekonomi Moneter dan Perbankan. 2019;21(3):343-366. https://doi. org/10.21098/bemp.v21i3.986

8. Kenjegaliev A., Duygun M., Mamedshakhova D. Do rating grades convey important information: German evidence? Economic Modelling. 2016;53:334-344. https://doi.org/10.1016/j.econmod.2015.11.021

9. Penha A.A.G. The effect of credit rating agencies in stock prices: Event study in Germany and Portugal. Master thesis. Lisboa: ISCTE Business School; 2015. 41 p. URL: https://repositorio.iscte-iul.pt/ bitstream/10071/11338/1/Thesis_Andr\%C3\%A9_ Alexandre_Gil_Penha.pdf

10. Gatti S., Colla P., Calderoni F. Rating changes: The European evidence. SSRN Electronic Journal. 2009. https://doi.org/10.2139/ssrn.1426523

11. Matolcsy Z.P., Lianto T. The incremental information content of bond rating revisions: The Australian evidence. Journal of Banking \& Finance. 1995;19(5):891-902. https://doi.org/10.1016/03784266(94)00082-E

12. Creighton A., Gower L., Richards A.J. The impact of rating changes in Australian financial markets. Pacific-Basin Finance Journal. 2007;15(1):1-17. https://doi.org/10.1016/j.pacfin.2006.04.003

13. Miyamoto M. Event study of credit rating announcement in the Tokyo stock market. Journal of Economics, Business and Management. 2016;4(2):138143. https://doi.org/10.7763/joebm.2016.v4.380

14. Morseth K., Nørgaard P. The impact of credit rating announcements on Norwegian equities: An event study on Oslo stock exchange. Master thesis. Bergen: Norges Handelshøyskole; 2011. 91 p. URL: https://openaccess.nhh.no/ nhh-xmlui/bitstream/handle/11250/169475/ Knut\%20Morseth\%20and\%20Peter\%20Norgaard. pdf? sequence $=1$ \&isAllowed $=y$

15. Randefelt A.L., Magnúsdóttir I. The effect of credit rating announcement in the Nordic stock market. Master's program in finance. Lund: Lund University; 2016. 42 p. URL: https://lup.lub.lu.se/luur/downloa $\mathrm{d}$ ? func $=$ downloadFile\&recordOId $=8876309 \&$ fileO $\mathrm{Id}=8876311$

16. Elayan F.A., Hsu W.H., Meyer T.O. The informational content of credit rating announcements for share prices in a small market. Journal of Economics and Finance. 2003;27(3):337-356. https://doi.org/10.1007/ BF02761570. 
17. Linciano $\mathrm{N}$. The reaction of stock prices to rating changes. SSRN Electronic Journal. 2004. https://doi. org/10.2139/ssrn.572365

18. Schweitzer R., Szewczyk S.H., Varma R. Bond rating agencies and their role in bank market discipline. Journal of Financial Services Research. 1992;6(3):249263. https://doi.org/10.1007/BF01047083

19. Jones E., Mulet-Marquis Q. The stock market reaction to changes to credit ratings of US-listed banks. SSRN Electronic Journal. 2013. https://doi.org/10.2139/ ssrn.2331914

20. Salvador C. Effect of signals of bank ratings on stock returns before and during the financial crisis. The Spanish Review of Financial Economics, 2017;15(1):111. https://doi.org/10.1016/j.srfe.2017.01.002

21. Lobão J., Pacheco L., Campos S. Stock price effects of bank rating announcements: An application to European Union countries. International Journal of Finance \& Economics. 2019;24(1):4-19. https://doi. org/10.1002/ijfe.1645

22. Chodnicka-Jaworska P. Banks' credit rating changes and the stock prices - The impact of political divisions and economy development. Review of Socio-Economic Perspectives. 2016;1(1):58-81. URL: https://reviewsep.com/my_documents/my_files/11_ Patrycja\%20Chodnicka-Jaworska_METIN.pdf

23. Han S., Shin Y., Reinhart W., Moore W.T. Market segmentation effects in corporate credit rating changes: The case of emerging markets. Journal of Financial Services Research. 2009;35(2):141-166. https://doi.org/10.1007/s10693-008-0049-0

24. Chandrashekar R., Mallikarjunappa T. Impact of bond rating on stock returns. Paripex - Indian Journal of Research. 2013;2(4):263-267. https://doi. org/10.36106/paripex

25. Rao S.V.D., Sreejith U. Impact of credit ratings (upgrade and downgrade) on stock prices in India. In: Proc. $23^{\text {rd }}$ International Business Research Conference (Melbourne, Nov. 18-20, 2013). 2013. URL: https://studylib.net/doc/13326876/proceedingsof-23rd-international-business-research-confe...

26. Archana H.N., Jayanna S., Hiremath V. Impact of bond rating changes on stock prices in India: Rating agency wise analysis. Indian Journal of Research in Capital Markets. 2015;2(4):20-32.

27. Murcia F.C.S., Murcia F.D., Borba J.A. The informational content of credit ratings in Brazil: An event study. Revista Brasileira de Finanças. 2013;11(4):503-523. https://doi.org/10.12660/rbfin. v11n4.2013.9264

28. Baraccat B.B., Bortoluzzo A.B., Gonçalves A.B. Rating changes and the impact on stock prices. Revista Brasileira de Gestão de Negócios. 2020;22:539-557. https://doi.org/10.7819/rbgn.v22i0.4064

29. Mokoaleli-Mokoteli T. The corporate credit rating changes and firm returns in a transitional economy: The case of South Africa. South African Journal of Business Management. 2019;50(1):460. https://doi. org/10.4102/sajbm.v50i1.460

30. Poomima B. G., Umesh N. P., Reddy Y. V. The Impact of Changes in Credit Ratings on Stock Returns. Journal of Financial Risk Management. 2015;12(3):5267.

31. Tripathi T. Impact of credit rating changes on stock prices in India - A study of banking sector. International Journal of Advance Research and Innovative Ideas in Education. 2017;3(3):3797-3806. https://doi.org/16.0415/IJARIIE-5771

32. Habib Y., Nazir M., Hashmi S., Saeed M.B. Credit rating announcements and stock returns: Evidence from the banking sector of Pakistan. Journal of Business Studies Quarterly. 2015;7(2):6184. URL: https://www.proquest.com/openvie w/910a4c42484103e91b7039fac5a3571a/1?pqorigsite $=$ gscholar\&cbl $=1056382$

33. Wang S. The effect of bond rating changes on stock returns: Evidence from the China \& Hong Kong stock market. Master thesis. Singapore: Singapore Management University; 2010. URL: https://ink. library.smu.edu.sg/etd_coll_smu/14/

34. Huang B., He L., Xiong S., Zhang Y. The impact of bond rating downgrades on common stock prices in China. Economic and Political Studies. 2018;6(2):209-220. https://doi.org/10.1080/20954816 .2018 .1463602

35. Hubler J., Louargant C., Laroche P., Ory J.-N. How do rating agencies' decisions impact stock markets? A meta-analysis. Journal of Economic Surveys. 2019;33(4):1173-1198. https://doi.org/10.1111/ joes. 12317

36. Studnikov S.S. A method of event analysis in research of profitability in corporate finance. Vestnik Instituta ekonomiki Rossiiskoi akademii nauk = Bulletin of the Institute of Economics of the Russian Academy of Sciences. 2012;(3):45-55. (In Russ.).

37. Naidenova I., Novikova A. The reaction of Russian public companies' stock prices to sanctions against Russia. Korporativnye finansy = Journal of Corporate Finance Research. 2018;12(3):27-38. https://doi. org/10.17323/j.jcfr.2073-0438.12.3.2018.27-38

38. Teplova T.V. Impact of dividend payments on the market valuation of Russian companies: Empirical research by event analysis on Russian and foreign trading platforms. Audit i finansovyi analiz $=$ Audit and Financial Analysis. 2008;(2):1-15. (In Russ.).

39. Berezinets I.V., Bulatova L.A., Il'ina Yu.B., Smirnov 
M.V. Russian stock market response to dividend "surprises": An empirical study. Rossiiskii zhurnal menedzhmenta = Russian Management Journal. 2016;14(2):29-48. (In Russ.).

40. Chirkova E.V., Chuvstvina E.V. Acquisition of private and public targets: Abnormal return in emerging markets. Korporativnye finansy $=$ Journal of Corporate Finance Research. 2011;5(3):30-43. (In Russ.). https://doi.org/10.17323/j.jcfr.20730438.5.3.2011.30-43

41. Khusainov Z.I. M\&A deal efficiency: Integrated evaluation methodology. Korporativnye finansy $=$ Journal of Corporate Finance Research. 2008;2(1):1233. (In Russ.). https://doi.org/10.17323/j.jcfr.20730438.2.1.2008.12-33

42. Skvortsova I.V., Proskurin S.S., Kryhtin V.B. et al. Event study methodology in M\&A research: Evidence from developed and emerging capital markets. Korporativnye finansy $=$ Journal of Corporate Finance Research. 2013:7(4):111-125. (In Russ.). https://doi.org/10.17323/j.jcfr.20730438.7.4.2013.111-125

43. Yavorskaya A.V., Yavorskii V.M. Event study method using cross-listing data on Russian companies as an example. Vesti vysshikh uchebnykh zavedenii Chernozemyya. 2015;(1):95-105. (In Russ.).

44. Pogozheva A.A. Event study analysis application for testing of the information value of analyst recommendations on Russian public companies. Korporativnye finansy $=$ Journal of Corporate Finance Research. 2013;7(2):35-49. (In Russ.). https:// doi.org/10.17323/j.jcfr.2073-0438.7.2.2013.35-49

45. Khlyupina N.A., Berzon N.I. The impact of analysts' recommendations on stock prices in Russia. Finansy i kredit $=$ Finance and Credit. 2016;(11):15-31. (In Russ.).

46. Ball R., Brown P. An empirical evaluation of accounting income numbers. Journal of Accounting Research. 1968;6(2):159-178. https://doi. org/10.2307/2490232

47. Fama E.F., Fisher L., Jensen M.C., Roll R. The adjustment of stock prices to new information. International Economic Review. 1969;10(1):1-21. https://doi.org/10.2307/2525569

48. Corrado C.J. Event studies: A methodology review. Accounting \& Finance. 2011;51(1):207-234. https:// doi.org/10.1111/j.1467-629X.2010.00375.x

49. Malyshenko K.A. Event studies in stock market. Vol. 1. Moscow: RuScience; 2017. 222 p. (In Russ.).

50. Nikitina T.V. et al. Fundamentals of portfolio investment. 2nd ed. Moscow: Yurait; 2018. 195 p. (In Russ.).

51. Studnikov S.S. Empirical and theoretical aspects of event risk assessment in company valuation. Moscow: RAsNEPA; 2017. 96 p. (In Russ.).

52. Bowman R.G. Understanding and conducting event studies. Journal of Business Finance \& Accounting. 1983;10(4):561-584. https://doi. org/10.1111/j.1468-5957.1983.tb00453.x

53. De Jong F. Event studies methodology. Unpublished paper. Tilburg: Tilburg University; 2007. URL: https://d1wqtxts1xzle7.cloudfront.net/55108295/ De_Jong_2007.pdf 